\title{
Kualitas Organoleptik dan Fisik Ampas Tahu yang Difermentasi Kapang Neurospora sitophila dan Trichoderma viridae sebagai Bahan Pakan Konsentrat
}

\author{
Budiyanto $^{1 *}$, Wardhana Suryapratama ${ }^{2}$, Sri Rahayu ${ }^{2}$ \\ ${ }^{1}$ Politeknik Pembangunan Pertanian Yogyakarta Magelang \\ ${ }^{2}$ Fakultas Peternakan, Universitas Jenderal Soedirman \\ *Corresponding author: Boedyyanto83@gmail.com
}

\begin{abstract}
Abstrak
Ampas tahu memiliki kandungan nutrien tinggi dan telah lama dimanfaatkan sebagai bahan pakan ternak, namun ampas tahu memiliki kekurangan yaitu daya simpan yang singkat sehingga diperlukan teknologi fermentasi. Fermentasi menggunakan kapang Neurospora sitophila (NS) dan Trichoderma viridae (TV) diharapkan menjadi solusi terkait permasalahan tersebut. Penelitian menggunakan teknik fermentasi aerob fakultatif, metode Rancangan Acak Lengkap 6 perlakuan diulangan 4 kali, Pengamtan Organoleptik, kualitas Fisik dan Kualitan Nutrient produk fermentasi. Kombinasi lama fermentasi 0,4 dan 8 hari (B1,B2,B3) dan jenis kapang yaitu Neurospora sitophila (A1) dan Trichoderma viridae (A2). Data dianalisis dengan uji F, apabila berpengaruh nyata maka dilanjutkan dengan Uji Duncan atau Duncan Multiple Range Test (DMRT) pada taraf 5\%. Terdapat perbedaan nyata dari pengunaan kapang dan lama fermentasi terhadap suhu akhir $\mathrm{p}<0,05$, terdapat perbedaan nyata dari pengunaan kapang dan lama fermentasi terhadap derajat keasaman $\mathrm{pH}$ akhir $\mathrm{p}<0,05$, terdapat perbedaan nyata antara lama fermentasi terhadap warna sebelum dikeringkan $\mathrm{p}<0,05$, Terdapat perbedaan nyata dari pengunaan kapang dan lama fermentasi terhadap warna setelah dikeringkan $\mathrm{p}<0,05$, Terdapat perbedaan nyata dari pengunaan kapang dan lama fermentasi terhadap tekstur sebelum dikeringkan $\mathrm{p}<0,05$, terdapat perbedaan nyata dari jenis kapang dan waktu lama fermentasi terhadap Tekstur setelah dikeringkan $\mathrm{p}<0,05$, Terdapat perbedaan nyata dari pengunaan jenis kapang dan waktu lama fermentasi terhadap Aroma setelah dikeringkan $\mathrm{p}<0,05$. Ampas tahu yang difermentasi menggunakan kapang Neurospora sitophila selama 8 hari menghasilkan produk terbaik sebagai bahan pakan konsentrat.
\end{abstract}

Kata kunci: Kapang, Fermentasi, Ampas tahu, Organoleptik, Kualitas fisik

\begin{abstract}
Tofu dregs have high nutrient content and have long been used as animal feed ingredients, but tofu dregs have shortcomings, namely short shelf life, so fermentation technology is needed. Fermentation using Neurospora sitophila (NS) and Trichoderma viridae (TV) is expected to be a solution to these problems. The research used facultative aerobic fermentation technique, completely randomized design method 6 treatments repeated 4 times, Organoleptic Treatment, Physical quality and Nutrient quality of fermentation products. The combination of fermentation time of 0.4.8 days (B1, B2, B3) and types of fungi are Neurospora sitophila (A1) and Trichoderma viridae (A2). Data were analyzed by using the F test, if it has a significant effect, then it is followed by the Duncan Test or Duncan Multiple Range Test (DMRT) at the 5\% level. There was a significant difference between the use of mold and the duration of fermentation against the final temperature $p$ $<0.05$, there was a significant difference between the use of mold and the length of fermentation on the degree of acidity at the final $\mathrm{pH} p<0.05$, there was a significant difference between the length of fermentation and the color before drying $p<0.05$, There is a significant difference between the use of mold and the duration of fermentation on the color after drying $p<0.05$, There is a significant
\end{abstract}


Prosiding Seminar Nasional Pembangunan dan Pendidikan Vokasi Pertanian Politeknik Pembangunan Pertanian Manokwari, 14 November 2020

e ISSN : 2774-1982

difference between the use of mold and the length of fermentation on the texture before drying $p$ $<0.05$, there is a significant difference in the type of mold and time duration of fermentation on texture after drying $p<0.05$, there is a significant difference in the use of the type of mold and the length of time for fermentation to aroma after drying $p<0.05$. Tofu dregs fermented using Neurospora sitophila for 8 days produced the best product as a concentrate feed ingredient.

Key words: Mold, Fermentation, Tofu dregs, Organoleptic, Phsical quality

\section{PENDAHULUAN}

Pakan merupakan salah satu aspek penting dalam usaha peternakan. Kualitas pakan yang diberikan akan mempengaruhi produktivitas ternak Dalam menentukan bahan pakan tenak ada beberapa hal yang perlu dipertimbangkan antara lain kandungan nutrisi dan juga kualitas fisik atau organoleptik dari bahan pakan tersebut hal tersebut sesuai pendapat Church dan Pond, (1988). Faktor yang mempengaruhi tingkat konsumsi diantaranya adalah penampilan dan bentuk makanan, aroma, rasa, tekstur, dan temperatur lingkungan. Tekstur, warna, aroma dan rasa yang disukai ternak menunjukkan bahwa kualitas pakan sangat baik yang berpengaruh terhadap palatabilitas (Christi $d k k, 2018$ )

Ampas tahu merupakan hasil sampingan dari limbah olahan industri kedelai menjadi tahu, diketahuai bahwa ampas tahu banyak memiliki nilai nutrisi yang bisa dimanfaatkan sebagai pakan ternak akan tetapi juga memiliki kekurangan yaitu kadar air yang tinggi sehingga menyebabkan cepat rusak. Ditinjau dari komposisi kimianya ampas tahu dapat digunakan sebagai bahan pakan sumber protein.

Teknologi fermentasi merupakan teknologi pengawetan yang biasa dipergunakan dan mudah diaplikasikan dimasyarakat, serta proses yang relative mudah dan singkat dalam prosesnya, fermentasi merupakan aplikasi metabolisme mikroba untuk mengubah bahan baku menjadi produk yang bernilai lebih tinggi, seperti asam-asam organik, protein sel tunggal, biopolimer, dan antibiotika (Lestari, 2001). Pada fermentasi terjadi proses yang menguntungkan di antaranya dapat menghilangkan bau yang tidak diinginkan, meningkatkan daya cerna, menghilangkan daya racun yang terdapat pada bahan mentahnya, dan menghasilkan warna yang diinginkan. Mikroba yang banyak digunakan sebagai inokulum fermentasi adalah kapang, bakteri, dan khamir. Pertumbuhan kapang mudah dilihat 
Prosiding Seminar Nasional Pembangunan dan Pendidikan Vokasi Pertanian

Politeknik Pembangunan Pertanian Manokwari, 14 November 2020

e ISSN : 2774-1982

karena penampakannya yang berserabut seperti kapas berwarna putih (Sukarminah et al., 2008).

Neurospora sitophila (N. sitophila) merupakan kapang karotenogenik yang menghasilkan berbagai enzim yaitu selulase, fitase, protease dan amilase yang termasuk dalam kelompok generated as safe (GRAS) (Schuster et al., 2002; Davis dan Perkins, 2002; Kanti., 2017). Trichoderma viridae merupakan kapang saprophyt yang banyak dimanfaatkan untuk proses fermentasi, karena kapang ini dapat menghasilkan enzim selulase kompleks. Enzim tersebut mempunyai kemampuan untuk menghidrolisa total selulase murni yang tidak dapat larut menjadi glukosa. Penguraian selulosa menjadi glukosa akan meningkatkan populasi mikroba terutama yang bersifat selulolitik (Autrey 1974, Leng 1991; Aisjah, 2001).

Atas dasar daya simpan ampas tahu yang pendek dan kandungan serat kasar tinggi perlu dilakukan penelitian untuk mengahasilkan produk ampas tahu yang memiliki kualitas lebih bagus dan daya simpan lama.

Mengkaji metode inkubasi fakultatif serta waktu fermentasi terbaik dari penggunaan kapang $\mathrm{N}$. sitopila dan $\mathrm{T}$. viridae pada sampas tahu ditinjau dari kualitas Organoleptik (suhu dan $\mathrm{pH}$ ) serta Kualitas Fisik (warna sebelum dikeringkan, warna setelah dikerinkan, tekstur sebelum dikeringkan, aroma sebelum dikeringkan dan tekstur sesudah dikeringkan).

\section{METODE}

Bahan yang digunakan dalam penelitian fermentasi ampas tahu adalah; Ampas tahu, kapang Trichoderma viridae dan Neurospora sitopila. Alat yang digunakan dalam penelitian fermentasi ampas tahu adalah timbangan, oven pengering, $\mathrm{Ph}$ meter, thermometer digital, pengepres, karung plastic, terpal, tong. Pengamatan hasil Fermentasi ampas tahu menggunakan 2 jenis kapang yaitu Neurospora sitopila lama waktu fermentasi yaitu 0, 4, 8 hari dan Trichorderma Viridae lama waktu fermentasi yaitu 0, 4, 8 hari. Metode penelitian yang digunakan Rancangan Acak Lengkap (RAL) dengan 6 perlakuan dan ulangan 4 kali sehingga diperoleh 24 unit percobaan. Data dianalisis dengan uji F, apabila berpengaruh nyata maka dilanjutkan dengan Uji Duncan atau Duncan Multiple Range Test (DMRT) pada taraf 5\%. Peubah yang diukur dan diamati yaitu warna, bau, suhu, $\mathrm{pH}$, tekstur. 
Prosiding Seminar Nasional Pembangunan dan Pendidikan Vokasi Pertanian

Politeknik Pembangunan Pertanian Manokwari, 14 November 2020

e ISSN : 2774-1982

Tabel 1. Kombinasi Perlakuan Tahap pertama

\begin{tabular}{ccccc}
\hline Perlakuan & \multicolumn{5}{c}{ Ulangan } \\
& 1 & 2 & 3 & 4 \\
\hline A1B1 & A1B1u1 & A1B1u1 & A1B1u1 & A1B1u1 \\
A1B2 & A1B2 u2 & A1B2 u2 & A1B2 u2 & A1B2 u2 \\
A1B3 & A1B3 u3 & A1B3 u3 & A1B3 u3 & A1B3 u3 \\
A2B1 & A2B1 u1 & A2B1 u1 & A2B1 u1 & A2B1 u1 \\
A2B2 & A2B2 u2 & A2B2 u2 & A2B2 u2 & A2B2 u2 \\
A2B3 & A2B3u3 & A2B3u3 & A2B3u3 & A2B3u3 \\
\hline
\end{tabular}

Sumber : Olah Data Penelitian 2020

Model matematik untuk menganalisis data menggunakan analisis variansi menurut Steel dan Torrie (1993) sebagai berikut:

$$
\mathrm{Y}_{\mathrm{ijk}}=\mu+\alpha_{\mathrm{i}}+\beta_{\mathrm{j}}+\alpha \beta_{\mathrm{ij}}+\varepsilon_{\mathrm{ijk}}
$$

Keterangan:

$\mathrm{Y}_{\mathrm{ij}}=$ Respon peubah yang diukur yang mendapat perlakuan kapang ke i, lama inkubasi ke j dan ulangan ke $\mathrm{k}$.

$\mu \quad=$ Rataan umum peubah yang diukur

$\alpha_{\mathrm{i}} \quad=$ pengaruh perlakuan kapang ke $\mathrm{i}$

$\beta_{\mathrm{j}} \quad=$ pengaruh lama inkubasi ke $\mathrm{j}$

$\alpha \beta_{\mathrm{ij}}=$ pengaruh interaksi antara perlakuan kapang ke $\mathrm{i}$ dan lama inkubasi ke $\mathrm{j}$

$\varepsilon_{\mathrm{ijk}}=$ galat percobaan

$\mathrm{i} \quad=1,2$ (faktor jenis kapang)

$\mathrm{j} \quad=1,2,3$ (faktor lama inkubasi)

$\mathrm{k}=1,2,3,4$ (ulangan)

Bau, Warna, pH, tekstur

Untuk mengukur kualitas hasil fermentasi ditentukan secara organoleptik (fisik) meliputi: tekstur, bau/aroma, pH, suhu. Pengamatan ini dilakukan sebelum (awal) dan sesudah (akhir) proses fermentasi, kemudian hasil dari pengamatan dianalisis sidik ragam, apabila perlakuan berpengaruh terhadap peubah respon maka dilakukan uji lanjut Duncan atau Duncan Multiple Range Test (DMRT) pada taraf 5\% dan penjabaran deskriptif.

\section{Waktu dan Tempat}

Penelitian dilaksanakan pada Bulan September 2020 di Laboratorium pengolahan pakan dan kebun rumput serta Lab Nutrisi Politeknik Pembangunan Pertanian Yogyakarta Magelang. 
Prosiding Seminar Nasional Pembangunan dan Pendidikan Vokasi Pertanian

Politeknik Pembangunan Pertanian Manokwari, 14 November 2020

e ISSN : 2774-1982

\section{HASIL DAN PEMBAHASAN}

\section{Pengamatan Organoleptik}

\section{a. Suhu}

Pengukuran Suhu mempergunakan thermometer digital yang diletakkan pada substrat sebelum plastik penutup/Wrap terbuka seluruhnya dan ditunggu 60 detik, Pada hasil fermentasi menggunakan kapang dengan inkubasi berbeda memberikan pengaruh nyata yang perbedaan suhu yang relative kecil dari masing-masing perlakuan untuk Kapang Neurospora sitophila suhu berkisar diantara $25-26{ }^{\circ} \mathrm{C}$ dan Trichoderma viridae suhu berkisar diantara $23-26{ }^{\circ} \mathrm{C}$. Hasil analisis variansi menginformasikan bahwa perlakuan jenis kapang dan lama waktu fermentasi memberikan perbedaa nyata suhu akhir (Sig.(p)<0,05) dalam (Steinkraus dkk., 1965; Noverina, 2008) menyatakan Neurospora sitophila termasuk kapang mesophilik yang memiliki suhu optimum pertumbuhan sekitar $300{ }^{\circ} \mathrm{C}$ dengan angka kelembaban sekitar $70 \%$ sampai $90 \%$, sedangkan $\mathrm{pH}$ lingkungan yang dibutuhkannya berkisar antara 4,5 - 6,5. Kanti (2017), Fitase dan amilase dapat diproduksi dengan media ampas tahu oleh $N$. sitophila suhu inkubasi perlu dilakukan $30^{\circ} \mathrm{C}$ b. pH Akhir

Pengukuran $\mathrm{pH}$ menggunakan $\mathrm{pH}$ meter yang dengan cara mengencerkan produk dengan aquades hal tersebut dikarenakan substrat berbentuk semi padat sedangka $\mathrm{pH}$ meter yang dipakai hanya bisa membaca pada substart yang cair. Hasil analisis variansi menginformasikan bahwa perlakuan jenis kapang dan lama waktu fermentasi memberikan perbedaa nyata. $(\mathrm{p})<0,05)$ terhadap derajat keasaman $\mathrm{pH}$ pada perlakuan pengguna Neurospora sitophila mengalami penurunan $\mathrm{pH}$ dari 7,8 pada 0 hari dan menurun pada hari 8 dengan rata-rata $\mathrm{pH} \mathrm{5,4} \mathrm{hal} \mathrm{tersebut} \mathrm{sesuai} \mathrm{pendapat} \mathrm{sesuai} \mathrm{pendapat} \mathrm{(Steinkraus} \mathrm{dkk.,}$ 1965; Noverina, 2008), menyatakan Neurospora sitophila termasuk kapang mesophilik yang memiliki $\mathrm{pH}$ lingkungan yang dibutuhkannya berkisar antara 4,5 - 6,5, sedangkan untuk Trichoderma viride cenderung stabil $\mathrm{pH}$ yaitu dengan rata-rata $8 \mathrm{pH}$. Hal tersebut kemungkinan dipengaruhi oleh teknik fermentasi apabila dilakukan dengan minim oksigen atau fakultatif akan menyebabkan suasana menjadi asam begitu pula pada fermentasi dengan kapang Neurospora sitopila yang cenderung merombak protein ampas tahu menjadi glukosa.

\section{Pengamatan Kualitas Fisik}

\section{a. Warna sebelum dikeringkan}

Dalam pengamatan warna menggunakan 15 panelis yang berasal dari staf Polbangtan Yogyakarta Magelang Kampus Magelang, pengisian skoring warna dengan 
Prosiding Seminar Nasional Pembangunan dan Pendidikan Vokasi Pertanian Politeknik Pembangunan Pertanian Manokwari, 14 November 2020

e ISSN : 2774-1982

memberi penilaian pada tabel yang telah disiapkan dengan panduan pengisian skor $1=$ hitam, 2 = coklat, 4 = abu-abu dan skor 5 . = putih bersih. Hasil analisis variansi menginformasikan bahwa perlakuan jenis kapang dan lama waktu fermentasi tidak memberikan perbedaan nyata $(\mathrm{P}>0,05)$ terhadap produk fermentasi terkait warna sebelum dikeringkan yaitu abu-abu, hal tersebut dikarenakan inkubasi fakultatif menyebabkan miselium tidak mudah terkena udara bebas dan warna dapat stabil abu-abu. Novianti (2012) pigmen dapat terbentuk karena adanya rangsangan cahaya, sehingga konidia membentuk pigmen karotenoid yang berfungsi sebagai alat proteksi diri tetapi pigmen juga dapat teroksidasi karena adanya pengaruh udara, dan sinar matahari turut mengkatalisa terjadinya reaksi ini, oleh karena itu semakin panjang lama fermentasi akan menurunkan kadar $\beta$ karoten. Penggunaan dari masing-masing kapang dan lama inkubasi tidak begitu mempengaruhi Warna sebelum produk fermentasi dikeringkan hal tersebut dikarenakan suasana aerob fakultatif menyebabkan jamur tidak terkena secara langsung udara bebas menurut pengamatan diketahui perubahan warna pada miselium kapang neurospora sitopila dapat berwarna jingga apabila terkena udara bebas dengan metode fakultatif udara bebas dapat ditekan karena udara yang masuk diminimkan, sedangkan untuk kapang Trichoderma viride pertumbuhan kapang baru dimulai pada hari ke 5 sehing tidak akan memberikan warna yang signifikan (Novianti, 2012) menerangkan Produksi $\beta$-karoten terus meningkat seiring dengan konsentrasi starter dan lama fermentasi yang juga bertambah hingga sampai titik tertinggi yaitu sebagai titik optimalnya yaitu 125,2599 ppm dengan lama fermentasi selama 8,795 hari ( 8 hari 19 jam 4 menit 48 detik) dan konsentrasi starter sebesar $6,817 \%$ kemudian mengalami penurunan. Hal ini dapat disebabkan berbagai faktor, diantaranya dapat disebabkan karena nutrisi dan kandungan air pada media sudah mulai habis. Menurut Tannenbaum (1979); Novianti, (2012), turunnya aktivitas air juga menyebabkan degradasi $\beta$-karoten. Lama fermentasi dan konsentrasi starter pada media dapat menyebabkan turunnya kadar air akibat adanya pemakaian air yang digunakan Neurospora sitophila untuk pertumbuhannya.

\section{b. Warna setelah dikeringkan}

Dalam penelitian ini proses pengeringan dilakukan dengan menggunakan open dengan pengaturan suhu $60{ }^{\circ} \mathrm{C}$ dikarenakan produk rata-rata mengandung kadar air cukup tinggi $80 \%$ pengeringan dengan oven dilakuakn selama 3 hari, apabila dikeringkan secara alami dengan kondisi matahari bersinar terus dapat kering dalam 2 hari dengan cara pengeringan produk di buat tiis-tipis untuk hasil produk dengan oven ataupun alami tidak 
Prosiding Seminar Nasional Pembangunan dan Pendidikan Vokasi Pertanian

Politeknik Pembangunan Pertanian Manokwari, 14 November 2020

e ISSN : 2774-1982

begitu banyak perubahan. Pengisian skoring warna pengisian skor $1=$ hitam, $2=$ coklat, 4 $=$ abu-abu dan skor $5=$ putih bersih.

Hasil analisa varians menjelaskan bahwa Terdapat perbedaan nayat antara jenis kapang dan waktu lama fermentasi yang berbeda nyata terhadap warna setelah dikeringkan (Sig.(p) $<0,05)$. Perubahan warna pada produk fermentasi dipengaruhi oleh udara bebas, suhu dan cahaya, substart yang difermentasi kapang neurospora sitophila apabila telah selesai waktu inkubasi dibuka dan segera dikeringkan maka akan terjadi perubahan warna yang awalnya berwarna krem atau abu-abu-abu setelah mengalami proses pengeringan maka akan berubah menjadi jingga atau bahkan menjadi coklat apabila inkubasi lebih dari 4 hari, sedangkan pada produk yang difermentsi dengan kapang trichoderma perubahan produk setelah dikeringkan akan berubah menjadi sedikit hijau atau abu-abu hal tersebut dikarenakan trichoderma cenerung mengubah warna abu-abu.

Masing-masing kapang dengan lama inkubasi memberi perubahan yang berbeda kapang Neurospora sitopila cenderung memberi warna krem, jingga sampai coklat sedangkan kapang Trichoderma memberi warna yang relatif stabil yaitu hijau muda seperti diungkapkan dalam (Perkins \& Turner 1988; Nurfaizin, 2015). Kapang Neurospora dapat menghasilkan pigmen karotenoid. Karakteristik dari golongan ini adalah makro dan mikro konidianya berwarna kuning hingga jingga karena mengandung senyawa karoten. Fermentasi dengan menggunakan kapang karotenogenik Neurospora memberikan keuntungan lain yaitu meningkatnya kandungan karoten yang dihasilkan dari konidia yang berwarna jingga (Nurfaizin, 2015). Karotenoid berfungsi untuk memberikan pigmen warna kulit dan sebagai antioksidan yang aktivitasnya dapat menghambat peroksida lipida (Lee et al., 2010). Judoamidjojo et al., (1992) bahan pakan yang dilakukan proses fermentasi menghasilkan warna yang baik sesuai dengan asalnya. Perubahan warna yang terjadi disebabkan oleh proses respirasi aerobic yang berlangsung selama persediaan oksigen masih ada, sampai karbohidrat yang terkandung dalam bahan habis.

\section{c. Tekstur Sebelum Dikeringkan}

Dalam pengamatan tekstur menggunakan 15 panelis yang berasal dari staf Polbangtan, pengisian skor $1=$ kering, $2=$ agak kering (tidak menggumpal dan remah), 4 $=$ agak basah (agak menggumpal dan remah) dan skor $5=$ basah (mengumpal, berair). Cara pengamatan tekstur yaitu menyentuh langsung produk fermentasi dengan jari-jari dan memasukkan skor sesui panduan yang ada.

Dari analisa varian mengahsilkan terdapat perbedaan nyata dari antara jenis kapang dan waktu lama fermentasi yang berbeda terhadap tekstur sebelum dikeringkan 
Prosiding Seminar Nasional Pembangunan dan Pendidikan Vokasi Pertanian Politeknik Pembangunan Pertanian Manokwari, 14 November 2020

e ISSN : 2774-1982

(Sig.(p) $<0,05$ ). Penggunaan Kapang Neurospora sitophila cenderung menghasilkan produk yang bersifat basah dan berair hal tersebut dimungkinkan karena substrat ampas tahu sendiri masih sangat basah dengan kadar air waktu fermentasi mencapai $50 \%$ sedangkan hasil fermentsi dengan menggunakan Trichoderma viridae hamper sama yaitu basah dan sedikit berair hal tersebut juga sesuai dengan pendapat Telew (2013) Semakin sedikit kandungan air bahan maka akan dihasilkan tekstur produk fermentasi yang sedikit kering bahkan kering sekali, sebaliknya jika kandungan air tinggi maka dihasilkan tekstur yang agak basah.

Tekstur merupakan cara untuk menunjukkan rasa permukaan bahan yang sengaja dibuat untuk menghasilkan respon kualitas baik maupun buruk. Menurut Lang (1997) proses fermentasi menghasilkan tekstur yang berbeda tergantung dari jenis bahan yang digunakan. Kering atau tidaknya produk hasil fermentasi maka tekstur yang dihasilkan tergantung pada kadar air bahan Menurut Wainwright dan McVeigh (1976); Novianti (2012), pembentukan spora dalam jumlah besar terjadi pada masa pertumbuhan statis antara 5 dan 7 hari fermentasi pada kapang Neurospora sp. Tricoderma viride tidak mampu mendegradasi kandungan hemiselulosa. Hal ini diduga karena Selulosa tidak terdegradasi dengan baik. Selulosa menjadi sumber karbon penting untuk mendorong terbentuknya enzim-enzim pendegradasi hemiselulosa oleh jamur. Struktur ikatan hemiselulosa dan lignin pada lignoselulosa terbentuk secara kovalen dan melapisi selulosa. Struktur ini harus dimodifikasi dengan menghilangkan lignin untuk menghasilkan hidrolisis selulosa dan hemiselulosa lebih efisien (Hamelinck et al., 2005). Widiastuti (2013) menambahkan bahwa kualitas tekstur dipengaruhi oleh kadar air dan serat kasar pada pakan, pakan yang mengandung serat kasar tinggi akan membuat tekstur menjadi kasar.

\section{d. Tekstur sesudah dikeringkan}

Dalam pengamatan Tekstur menggunakan 15 panelis panduan pengisian skor $1=$ agak basah (agak menggumpal dan remah), 2 = agak kering (tidak menggumpal dan remah), 4 = Kering Remah, $5=$ Kering Keras. Dari analisa varian dapat dijelaskan bahwa terdapat perbedaan nyata antara jenis kapang dan waktu lama fermentasi yang berbeda terhadap Tekstru setelah dikeringkan (Sig. $(\mathrm{p})<0,05)$. Tekstur setelah dikeringkan menyatakan bahwa penggunaan kapang neurospora dengan lama inkubasi memberi pengaruh terhadap produk yang dikeringkan semakin lama inkubasi berpengaruh terhadap tingkat kekerasan produk, sedangkan penggunaan trichoderma memberikan tektur yang relative stabil Wainwright dan McVeigh (1976). Hank dan Sussman (1969); Murayama dan Ishikawa (1973); novianti (2012), pembentukan spora dalam jumlah besar terjadi pada 
Prosiding Seminar Nasional Pembangunan dan Pendidikan Vokasi Pertanian

Politeknik Pembangunan Pertanian Manokwari, 14 November 2020

e ISSN : 2774-1982

masa pertumbuhan statis antara 5 dan 7 hari fermentasi pada kapang Neurospora sp. Tricoderma viride tidak mampu mendegradasi kandungan hemiselulosa. Hal ini diduga karena Selulosa tidak terdegradasi dengan baik. Selulosa menjadi sumber karbon penting untuk mendorong terbentuknya enzim-enzim pendegradasi hemiselulosa oleh jamur.

Tekstur setelah dikeringkan kapang neurospora dengan lama inkubasi memberi pengaruh terhadap produk yang dikeringkan semakin lama inkubasi berpengaruh terhadap tingkat kekerasan produk, sedangkan penggunaan trichoderma memberikan tektur yang relatif stabil. Tekstur kapang Neurospora pada produk akhir dengan semakin lama waktu inkubasi akan menyebabkan tekstur semakin keras hal tersebut dimunkinkan karena ikatanikatan glukosa yang kering sehingga menyebabkan mengers, sedangkan untuk produk dari Trichoderma cenderung memberikan tekstur yang remah. Hank dan Sussman (1969); Murayama dan Ishikawa (1973): novianti (2012), pembentukan spora dalam jumlah besar terjadi pada masa pertumbuhan statis antara 5 dan 7 hari fermentasi pada kapang Neurospora sp. Tricoderma viride tidak mampu mendegradasi kandungan hemiselulosa. Hal ini diduga karena selulosa tidak terdegradasi dengan baik. Selulosa menjadi sumber karbon penting untuk mendorong terbentuknya enzim-enzim pendegradasi hemiselulosa oleh jamur. Struktur ikatan hemiselulosa dan lignin pada lignoselulosa terbentuk secara kovalen dan melapisi selulosa. Struktur ini harus dimodifikasi dengan menghilangkan lignin untuk menghasilkan hidrolisis selulosa dan hemiselulosa lebih efisien (Hamelinck et al., 2005). Widiastuti (2013), menambahkan bahwa kualitas tekstur dipengaruhi oleh kadar air dan serat kasar pada pakan, pakan yang mengandung serat kasar tinggi akan membuat tekstur menjadi kasar.

\section{e. Aroma setelah dikeringkan}

Dalam pengamatan Aroma menggunakan 15 panelis yang berasal dari staf Polbangtan panduan pengisian skor 1. AT Netral, 2. Menyengat Amoniak 4. Sangat khas fermentasi dan skor 5. Sangat khas fermentasi menyengat. Dari analisa varians diperoleh bahwa Terdapat perbedaan nyata dari pengunaan antara jenis kapang dan waktu lama fermentasi yang berbeda terhadap Aroma setelah dikeringkan (Sig.(p) $<0,05)$. Pproduk fermentasi dari kapang Neurospora sithophila lama inkubasi membrikan pengaruh terhadap aroma produk ferentasi semakin lama inkubasi menimbulkan aroma yang semakin khas yaitu wangi tape yang meningkat akan tetapi ada waktu maksimal. Sedangkan penggunaan trichoderma dengan lama inkubasi tidak terlalu berpenaruh terhadap aroma produk fermentasi yaitu berbau menyengat amoniak. Selama pertumbuhannya, Neurospora sitophlla menghasilkan beberapa enzim, diantaranya enzim yang paling dominan yaitu 
Prosiding Seminar Nasional Pembangunan dan Pendidikan Vokasi Pertanian Politeknik Pembangunan Pertanian Manokwari, 14 November 2020

e ISSN : 2774-1982

enzim lipase yang merombak lemak menjadi menjadi asam lemak bebas dan gliserol, enzim protease yang dapat memecah protein menjadi asam amino yang mudah dicerna sehingga lebih mudah diserap oleh tubuh, dan enzim amilase yang melakukan hidrolisis pada karbohidrat menjadi gula sederhana, alkohol atau ester yang menghasilkan citarasa dan aroma pada produk akhir menurut Shurtleff dan Aoyagi(1979); noverina 2008. Sineerart et al., (2013); Cristi dkk., (2018), menyatakan aroma fermentasi juga menentukan kualitas fisik, dimana warna yang baik akan menghasilkan pula aroma yang baik pula. Konsentrat fermentasi menghasilkan aroma yang sangat khas karena pada prosesnya terjadi proses fermentasi. Selama proses fermentasi terjadi reaksi aerob yang dibentuk pada hari ke 1-7 dengan produknya berupa asam lemak yang mudah menguap. Widiyastuti dkk., (2004) mengatakan bahwa aroma dipengaruhi oleh kandungan lemak, protein dan kadar air pada pakan. Tingginya kadar air pada pakan akan menyebabkan terjadinya oksidasi lemak yang akan mengakibatkan timbulnya aroma tengik. Selama pertumbuhannya, Neurospora sitophlla menghasilkan beberapa enzim, diantaranya enzim yang paling dominan yaitu enzim lipase yang merombak lemak menjadi menjadi asam lemak bebas dan gliserol, enzim protease yang dapat memecah protein menjadi asam amino yang mudah dicerna sehingga lebih mudah diserap oleh tubuh, dan enzim amilase yang melakukan hidrolisis pada karbohidrat menjadi gula sederhana, alkohol atau ester yang menghasilkan citarasa dan aroma pada produk akhir (Shurtleff dan Aoyagi, 1979; Noverina, 2008).

\section{KESIMPULAN DAN SARAN}

1. Ampas tahu hasil fermentasi Neurospora sitopila selama Delapan hari dapat meningkatkan kualitas Organoleptik dan kualitas fisik ampas tahu dengan spesifikasi warna coklat tua dan aroma yang khas wangi tape.

2. Ampas tahu yang di fermentasi menggunakan kapang Neurospora sitopila selama Delapan hari memberikan kualitas lebih baik dibanding kapang Trichoderma viridae

\section{DAFTAR PUSTAKA}

Aisjah, T. (2001). Pengaruh Takaran Inokulum (Trichoderma Viridae) Dan Suhu Fermentor Terhadap Nilai Gizi Protein Kasar Dan Serat Kasar Produk Fermentasi Bungkil Kelapa Sawit. Bionatura, 3(3).

Autrey, K.M. 1(974). Selulose Digestibility of Material Fibrous Treted With Tricoderma Viridae Selulose. Journal Dairy Science 58 Hal 67-77.

Church, D.C. \& W. G. Pond. (1988). Basic Animal Nutrition and Feeding. 3nd Ed. John Wiley and Son, New York. 
Prosiding Seminar Nasional Pembangunan dan Pendidikan Vokasi Pertanian

Politeknik Pembangunan Pertanian Manokwari, 14 November 2020

e ISSN : 2774-1982

Christi, R. F., Rochana, A., \& Hernaman, I. (2018). Kualitas Fisik dan Palatabilitas Konsentrat Fermentasi dalam Ransum Kambing Perah Peranakan Ettawa. Jurnal Ilmu Ternak Universitas Padjadjaran, 18(2), 121-125.

Hamelinck, C.N., G. van Hooijdonk, \& A.P.C. Faaij. (2005). Ethanol from lignocellulosic biomass: Techno-economic performance inshort-, midleand long-term. Biomass and Bioenergy 28: 384-410.

Judoamidjojo, M. Darwis, A., \& Sa’id, E.G. (1992). Teknologi Fermentasi. Penerbit Rajawali Pers, Jakarta.

Kanti, A. (2017). Potensi kapang Aspergillus niger, Rhizopus oryzae dan Neurospora sitophila. Buletin Peternakan, 41(1).

Lang, C., C. Golnitz, M. Popovic \& U. Stahl. (1997). Optimization of Fungal Polygalacturonase Synthesis by Saccharomyces cereviseae in Fed-Batch Culture. Chem. Eng. J 65:219-226.

Lee CY, Lee BD, Na JC, An G. (2010). Carotenoid accumulation and their antioxidant activity in spent laying hens as affected by polarity and feeding period. AsianAustralasian J Anim Sci. 23:799-805

Leng, R.A. (1991). Application of Biotechnology to Nutrition of Animals in Developing Countries, F.A.O. Animal Production and Health.

Lestari, S. (2001). Pengaruh Kadar Ampas Tahu Yang Difermentasi Terhadap Efisiensi Pakan dan Pertumbuhan Ikan Mas (Cyprinus carpio). Skripsi S1. Prodi Budidaya Perairan IPB, Bogor.

Melati, I., Mulyasari, M., \& Azwar, Z. I. (2012). Pengaruh fermentasi menggunakan trichoderma viride dan phanerochaete chrysosporium serta gabungan keduanya terhadap komposisi nutrien tepung jagung sebagai bahan baku pakan ikan. Jurnal Riset Akuakultur, 7(1), 41-47.

Novianti, T., Wignyanto, W., \& Nurika, I. (2012). optimization spores producing $\beta$-karoten of fungus neurospora sitophila by response surface method (On Fermentation Process Duration and Starter Concentration). Jurnal Teknologi Pertanian, 5(2).

Noverina, N., Harlina, T., Yolandasari, D., Septianie, A., Nugraha, K., Dhalika, T., \& Budiman, A. (2008). Evaluasi Nilai Nutrisi Tongkol Jagung Hasil Bioproses Kapang Neurospora Sitophila Dengan Suplementasi Sulpur Dan Nitrogen. Jurnal Ilmu Ternak Universitas Padjadjaran, 8(1).

Nurfaizin \& PR Matitaputty. (2015). Penggunaan Kapang Karotenogenik Neurospora dalam Fermentasi Limbah Pertanian untuk Pakan Ternak Unggas. Wartazoa Vol. 25 No. 4 Th. 2015 Hlm.189-196 DOI: http://dx.doi.org/10.14334/wartazoa.v25i4.1229

Nurhaita, N. J., Saladin, R., Warly, L., \& Mardiati, Z. (2008). Efek suplementasi mineral Sulfur dan Phospor pada daun sawit amoniasi terhadap kecernaan zat makanan secara in-vitro dan karakteristik cairan rumen. J. Pengembangan Peternakan Tropis, 33(1), 51-58.

Nurhaita, N., Definianti, N., \& Zurina, R. (2012). Fermentasi bagase tebu dengan Neurospora sitophila dan pengaruhnya terhadap nilai gizi dan kecernaan secara in vitro. Jurnal Embrio, 5(01), 1-7.

Perkins DD, \& Turner BC. (1988). Neurospora from natural populations: Toward the population biology of a haploid eukaryote. Exp Mycol. 12:91-131. 
Schuster, E., N. Dunn-Coleman, J. Frisvad, \& P. Van Dijck. (2002). On the safety of Aspergillus niger - A review. Appl. Microbiol. Biotechnol. 59: 426-435. http://doi.org/10.1007/s00253-002- 1032-6.

Shurtleff, W. and A. Aoyagi. (1975). The Book of Tofu, Food for Mankind. Ten Speed Press, California, USA.

Suprapti, M. L. (2005). Pembuatan Tahu, Seri Pengolahan Pangan. Penerbit Kanisius. Yogyakarta.

Telew, C., V.G Kereh., I.M Untu \& B.W. Rembet. (2013). Pengayaan Nilai Nutritif Sekam Padi Berbasis Bioteknologi "Effective Microorganisms" (EM4) Sebagai Bahan Pakan Organik. Jurnal Zootek. Januari Vol.32 No. 5. Fakultas Peternakan Universitas Sam Ratulangi Manado, 95115.

Utomo, R. (2013). Konservasi Hijauan Pakan dan Peningkatan Kualitas Bahan Pakan Berserat Tinggi. In Press.

Utomo, A. J. (2010). Palatabilitas Serta Rasio Konsumsi Pakan dan Air Minum Kelinci Jantan Lokal Peranakan New Zealand White yang diberi Pelet atau Silase Ransum Komplit. Institut Pertanian Bogor, Bogor. (Skripsi)

Widiyastuti, T., C. H. Prayitno, \& Munasik. (2004). Kajian kualitas fisik pelet pakan komplit dengan sumber hijauan dan binder yang berbeda. Animal Production. 6 (1) : $43-48$.

Widiastuti, R. (2013). Kualitas Pelet Berbasis Sisa Pangan Foodcourt dan Limbah Sayuran Fermentasi Sebagai Bahan Pakan Fungsional Ayam Broiler. 